\title{
Low-pressure fractional crystallization origin of the tholeiitic basalts of the Deccan plateau, India
}

\author{
Ken-ichiro AOKI*, Takeyoshi Yoshida** \\ Shigeo ARAMAKI ${ }^{* * *}$ and Hajime KURASAWA ${ }^{* * * *}$ \\ *Institute of Mineralogy, Petrology and Economic Geology, \\ Tohoku University, Sendai 980, Japan \\ **Deparlment of Earth Sciences, College of General Education, \\ Tohoku University, Sendai 980, Japan \\ ***Department of Geology and Mineralogy, Hokkaido University, \\ Sapporo 060. Japan \\ **** Geological Survey of Japan, Tsukuba 305, Japan
}

\begin{abstract}
Petrographic descriptions and mineralogical data have been presented together with analytical results of major and trace elements for tholeitic picritic basait - ferrobasalt suite from the Deccan plateau, India. The compositional relation between coexisting augite and pigeonite was elucidated. Wide variations of incompatible element abundances were recognized among the samples but their patterns of relative enrichments parallel one another. The rock suite was probably produced by partial melting of mantle peridotite with abundances of incompatible elements rather close to primordial abundances. However, the $\mathrm{Sr}$ isotopic abundances were highly variable in the source, as also were alkali and alkali earth elements to a lesser extent. Fractional crystallization under low-pressure conditions was a major process in the evolution of this rock sequence. Olivine $\left(\mathrm{F}_{85-30}\right)$ was predominant in the differentiation and plagioclase was probably also involved together with augite.
\end{abstract}

Keywords: Deccan plateau, Tholeitic basalt, Incompatible element, Sr isotope, Fractional crystallization

\section{Introduction}

Basaltic rocks forming the vast Deccan plateau are distributed over an area of $6.5 \times 10^{5}$ $\mathrm{km}^{2}$ in the western India subcontinent. Their volume total is about $5 \times 10^{5} \mathrm{~km}^{3}$ equivalent to the volume of other continental flood basalts such as Columbia River basalt, Stormberg basalt, and Parana basalt. The eruption of the Deccan basalts started in Late Cretaceous and ceased by Early Tertiary (100 -60 Ma), while it was more than $70 \mathrm{Ma}$ ago when the majority erupted (Kaneoka, 1980). According to Alexander (1981), however, some of the flows may be as young as $30 \mathrm{Ma}$. The lava pile reaches approximately $2,000 \mathrm{~m}$ thick in the west Deccan plateau, whereas the accumulation is $100-200 \mathrm{~m}$ in the east. The thickness of particular flows is variable; some are less than $1 \mathrm{~m}$, others are nearly $70 \mathrm{~m}$. Their estimated average thickness is $30 \mathrm{~m}$. Most of the Deccan basalts are tholeiitic but $5 \%$ or less are alkalic: they are alkali basalt, mugearite, nephelinite, ankaramite, trachyte, and other differentiated rocks.

Boss (1972) summarized the petrographical and geochemical characteristics of the Deccan basalts in a compilation of data available before 1970. Since then, Alexander and Gibson

(Manuscript received, June 18, 1992 ;

accepted for publication, June 30,1992 ) 


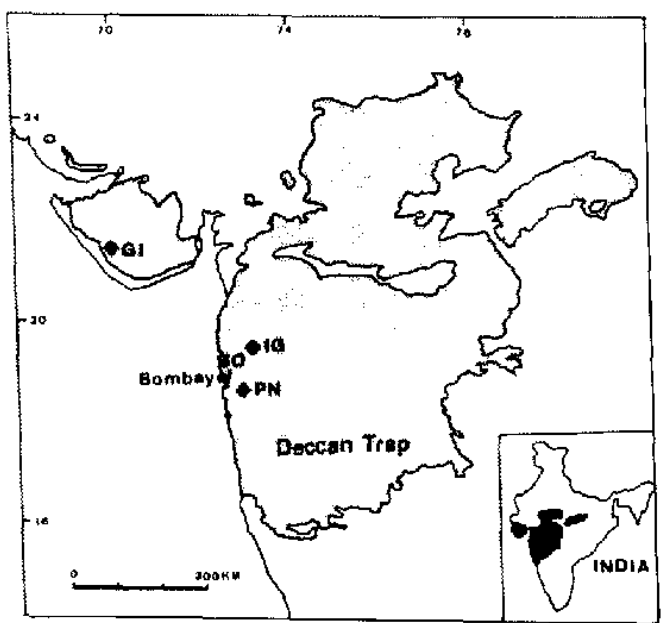

Fig. 1. Map showing the distribution and sample locality of Deccan basalts.

BO, Bombay island: PN, ThanaKhopoli; IG, Igatpuri; GI, Junagadh.

(1977) reported trace element data for some Deccan basalts, a number of geochemical data including $\mathrm{Sr}$ and $\mathrm{Nd}$ isotope ratios have been published (Alexander and Paul, 1977; Kuras. awa et al., 1982; Mahoney et al., 1982; Paul et al., 1984). However, to date, no study has produced a systematic set of petrographical and geochemical data for the Deccan basalts obtained on the same sample. Therefore, in this paper we report the results of a detailed petrography and mineralogy, together with major and trace element data for the picritic basalt - ferrobasalt association of a representative tholeiitic suite of the Deccan plateau.

\section{Sample Localities}

The Deccan basalts are distributed in the area shown in Fig. 1 and the investigated sam. ples are from Bombay and its environ (Bombay island, BO; Thana-Khopoli, PN ; Igatpuri, IG; Junagadh, GI). All the samples are tholeiitic basalts or tholeiitic dolerites. The Deccan basalts have been severely altered and fresh olivines and glasses were difficult to obtain. The alteration is especially conspicuous in the lavas. Therefore, less altered samples have been selected for the analysis through thin section examinations but some of them contain serpentinized olivines. They are picritic basalts - ferrobasalts and picritic dolerites-ferrodolerites; the latter were from dykes intruded into the lavas.

\section{Summary of Petrography}

We classified the samples using $\mathrm{Mg}$-value ; picritic basalt $>60$, basalt $60-30$, ferrobasalt $<30$. The samples with an ophitic texture are regarded as being dolerites.

The phenocryst usually make up less than $10 \%$ for the rocks and some rock are nearly aphyric (less than 1-2\%), while a few contain abundant phenocrysts that is up to $20 \%$. The phenocrysts are olivine, augite, and plagioclase. All the samples include olivine phenocryst shorter than $2 \mathrm{~mm}$, but some olivine phenocrysts are as long as $4 \mathrm{~mm}$. Plagioclase phenocrysts can be found in almost all the samples as well. Although most of them are shorter than $5 \mathrm{~mm}$, some are longer than $15 \mathrm{~mm}$. By contrast, augite phenocrysts are less frequently found.

The groundmass is composed of plagio. clase, olivine, clinopyroxene, and iron oxides (titanomagnetite and ilmenite) and a little apatite. Small to trace amounts of quartz, cristobalite, and alkali feldspar are observed in some samples. Brown glasses are observed even in the holocrystalline groundmasses. The groundmass olivine is not in reaction relation with pigeonite which appears with augite in some differentiated basaltic rocks. A trace amount of hornblende is found in a few samples. The mesostasis among the groundmass minerals in the coarse-grained ferrobasalts and ferrodolerites are filled with the light brown glasses that carry needle-shape plagioclase, fayalitic olivine, ferroaugite, ferropigeonite, titanomagnetite, ilmenite, alkali feldspar, quartz, and apatite. 
Table 1. Major and trace element analyses of Deccan tholeitic basalts

\begin{tabular}{|c|c|c|c|c|c|c|c|c|c|c|c|c|c|c|c|}
\hline $\begin{array}{l}5 p+\text { ko. } \\
\text { kock name* }\end{array}$ & $\begin{array}{c}1 \\
G:-69 \\
\text { A } 0 \text { do } 1 .\end{array}$ & $\begin{array}{c}2 \\
a l-67 \\
0 \text { dol. }\end{array}$ & $\begin{array}{c}3 \\
61-68 \\
0 \text { to1. }\end{array}$ & $\begin{array}{c}4 \\
61-66 \\
0 \text { dol. }\end{array}$ & $\begin{array}{c}5 \\
\text { ct-70 } \\
\text { tot. }\end{array}$ & $\begin{array}{c}6 \\
\text { PN-27 } \\
0 \text { bas. }\end{array}$ & $\begin{array}{c}? \\
\text { BO-zl } \\
0 \text { \& bas. }\end{array}$ & $\begin{array}{c}\text { B } \\
\text { PN-21 } \\
\text { F.dol. }\end{array}$ & $\begin{array}{c}9 \\
\text { PN-26 } \\
\text { F.dal. }\end{array}$ & $\begin{array}{c}10 \\
P N-30 \\
0 f, d c l .\end{array}$ & $\begin{array}{c}13 \\
P N-29 \\
\text { F.dol. }\end{array}$ & $\begin{array}{c}12 \\
\text { PN-23 } \\
\text { F. bas }\end{array}$ & $\begin{array}{c}13 \\
1 G-04 / 0 \\
\text { F.bas. }\end{array}$ & $\begin{array}{c}14 \\
B 0-30 \\
F . d 01 .\end{array}$ & $\begin{array}{c}\{5 \\
\text { PN-22 } \\
\text { F.dol. }\end{array}$ \\
\hline $\mathrm{SiO}_{\mathrm{z}}$ & 46.80 & 44.90 & 49. 81 & 49.10 & 49.30 & 46.43 & 48.67 & 48.35 & 47.78 & 48.82 & 49.1 .3 & 49.51 & 49.96 & 50. E? & 50.08 \\
\hline $\mathrm{TSO}_{2}$ & 1.06 & 1.17 & 1.22 & t. 31 & 1.25 & 1,41 & 1.98 & 2.57 & 3.04 & 2.16 & 2.79 & $3: 01$ & 2.70 & 2.52 & 3.70 \\
\hline $\mathrm{Al}_{2} \mathrm{O}_{3}$ & 13.48 & 16.04 & 13.70 & 13.91 & 15,37 & 15.62 & 14.04 & 13.28 & 13.63 & $\{2.7\}$ & 13.11 & :2.15 & 12.63 & 13.22 & 11.88 \\
\hline $\mathrm{Fe}_{3} \mathrm{O}_{3}$ & 2.51 & 2.37 & 2.04 & 2.49 & 2.23 & 5.49 & 5.12 & 2.28 & 2.56 & 3.50 & 3.58 & 3.97 & 2.48 & 3.41 & 3.85 \\
\hline гаอ & 9.27 & 9.05 & 8.65 & 9.58 & B. 64 & 5.62 & 6.75 & 11.90 & $11.4 \div$ & 19.29 & 50.92 & $\$ 1.50$ & 12.60 & 11.69 & $\$ 1.4 ?$ \\
\hline *na & 0.19 & 0.19 & 0.18 & 0.18 & 0.19 & 0.18 & 0.16 & 0.24 & 0.20 & 0.24 & 0.22 & 0.25 & 0.22 & 0.22 & 0.26 \\
\hline $\mathrm{mol}$ & 12.66 & 11.15 & 8.61 & B. 54 & 5.94 & 7.67 & 3.00 & 5.21 & 6.20 & 5.93 & 5.85 & 5.27 & 9.80 & 4.38 & 4,15 \\
\hline CA 0 & 9.12 & 10.03 & 10.60 & 10.52 & 11.06 & 9.92 & 11.21 & 11.37 & $10.6^{f}$ & 10.38 & 10.60 & $10 . \$ 1$ & 9.02 & 8.44 & 9.34 \\
\hline $\mathrm{ma}_{2} \mathrm{E}^{\mathrm{O}}$ & 1.69 & 1.99 & 1.89 & 2.08 & 2.14 & 2.13 & 2.22 & 2.25 & 2.45 & 2.27 & 2.33 & 2.33 & 2.64 & 2.70 & 2.45 \\
\hline$R_{2} 0$ & 0.43 & 0.41 & 0.69 & 0.60 & 0.57 & 0.49 & 0.20 & 0.56 & 0.69 & 0.45 & 0.63 & 0.65 & 0.54 & 0.98 & 1.24 \\
\hline $\mathrm{P}_{2} \mathrm{~A}_{5}$ & a.11 & 0.13 & 0.12 & 0.92 & 0.59 & 8.13 & 0.23 & 0.19 & 0.28 & 0.20 & 0.27 & 0.26 & $0.2 B$ & 0.38 & 0.81 \\
\hline 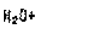 & 2.35 & 1.51 & 1.45 & 1.09 & 1.66 & 1.32 & 1.02 & 0.66 & 0.98 & 0.82 & 0.73 & 0.71 & 0.73 & 0.7 & 0.68 \\
\hline $\mathrm{H}_{2} \mathrm{O}-$ & 0.43 & 0.35 & 0.51 & 0.29 & 0.62 & 2.38 & 1.43 & 0.50 & 0.49 & 0.94 & 0.61 & 0.87 & 0.91 & 1.20 & 1.02 \\
\hline Total & 100.10 & S00.00 & 99.47 & 99.79 & $: 00.06$ & 100.79 & 100.03 & 100.36 & 100.32 & 99.77 & 100.67 & 100.89 & 99.51 & 100.18 & 100.53 \\
\hline ga pen & 119 & 90 & 143 & $20 \hat{2}$ & 139 & 214 & 159 & 110 & 188 & 120 & 204 & 167 & 340 & 475 & 252 \\
\hline Ce & 12.7 & 14.4 & 22.5 & 22.2 & 19.1 & 18.5 & 27.5 & 20.8 & 41.1 & 25.2 & 29.6 & 35.0 & 45.9 & 64.6 & 62.1 \\
\hline Ed & 66.3 & 68.7 & 49.9 & 53.9 & 46.5 & 65.6 & 46.2 & 54.5 & 49.0 & 52.8 & 48.5 & 47.5 & 49.3 & 46.7 & 43.9 \\
\hline Er & 408 & 406 & 329 & 296 & 248 & 74.2 & 285 & 74.6 & 242 & 52.4 & 87,4 & 60.6 & 19.7 & 32.5 & 56.6 \\
\hline cs & 0.07 & 0.31 & 0.45 & D. 48 & 0.37 & - & - & - & 0.22 & - & - & - & 1.55 & 0.56 & - \\
\hline $\mathbf{F}$ & 159 & 137 & 235 & 227 & 156 & - & 229 & 222 & 357 & 254 & 28! & 381 & 405 & 414 & 521 \\
\hline 乩 & 5.0 & 5.8 & 6. 3 & 6.1 & 4.9 & 5.2 & 9.8 & 9.9 & 23.9 & 10.0 & 13.2 & 14.5 & 13.3 & 29,4 & 20.3 \\
\hline$x !$ & 374 & 356 & 140 & 109 & 105 & 205 & 116 & 85.6 & 122 & 59.4 & 91.1 & 48.5 & 56.5 & 27.6 & 43.3 \\
\hline pb & 13.4 & 10.5 & 25,2 & 18.9 & 12.4 & 7.3 & 2.5 & 11.6 & 12.8 & 7.2 & 13.8 & 17.0 & 18.7 & 20.3 & 24.1 \\
\hline $5 x$ & 25.6 & 24.9 & 29.4 & $35 . \therefore$ & 34.0 & 26.1 & 30.4 & 44.9 & 41.8 & 35.5 & 33.5 & 41.1 & 40.2 & 36.3 & 45.5 \\
\hline $5 r$ & 105 & 156 & 131 & 153 & 155 & $\$ 14$ & 211 & 177 & 270 & 196 & 194 & 175 & 233 & 299 & 211 \\
\hline$\gamma$ & 208 & 294 & - & - & 254 & - & 344 & $43 \mathrm{~B}$ & 371 & 382 & - & - & 363 & 427 & 420 \\
\hline$y$ & 21.6 & 23.3 & 22.6 & 24.9 & 25.6 & 22.2 & 28.3 & 30.1 & 32.3 & 23.7 & 34.4 & 37.6 & 44.2 & 37.7 & 47.8 \\
\hline $2 n$ & 98 & 69 & 81 & 97 & 66 & 54 & 96 & 106 & 134 & 162 & 139 & 148 & 132 & 166 & 162 \\
\hline $2 r$ & 76.8 & 80.1 & 85.8 & 87.0 & 89.6 & 91.8 & 124 & 122 & 171 & 128 & 154 & 184 & 190 & 193 & 270 \\
\hline$\left({ }^{\prime \prime} 5 r\right)^{40}$ & 0.30915 & & & & & & & & - & & 0.7 & & & & \\
\hline
\end{tabular}

- A, augite; O, olivine; bas., basa1t; F.dol., ferrodolerite; f.bas., ferrobasalt. to Kuras awa et al., 1982.

\section{Chemistry}

Analytical methods: Major element com. positions were determined by conventional wet chemical methods for silicate analysis, combined with flame photometric and atomic absorption spectroscopic techniques, Most of the trace elements were determined by nondestructive photon activation analysis with gamma ray spectrometry at the Laboratory of Nuclear Science, Tohoku University. Detailed procedures and accuracy of the analysis are given by Yoshida et al. $(1981,1986)$. Fluorine was determined using a selective ion-electrode method (Kanisawa, 1979) adapted from the procedure outlined by Ingram (1970) and Kesler et al. (1973). The $\mathrm{Sr}$ isotopic ratios were determined by a solid-source mass spectrometer (VG 354) at Geological Survey of Japan.
Major elements: Table 1 gives the major and trace elements abundances and $\mathrm{Sr}$ isotopic ratios for fifteen representative samples. A narrow range in $\mathrm{SiO}_{2}$ is one of the characteristic chemical features of flood basalts. The analytical results of $\mathrm{SiO}_{2}$ are between 45.8 and $52.8 \mathrm{wt} \%$ (water-free basis); these samples are not exceptional. The other major elements vary greatly among the samples. We used the $\mathrm{SiO}_{2}-\mathrm{Na}_{2} \mathrm{O}+\mathrm{K}_{2} \mathrm{O}$ diagram to classify the samples in this study. All the analytical results plot in Fig. 2 where the boundaries between alkali and high-alumina basalts $\left(\mathrm{Al}_{2} \mathrm{O}_{3}>16.5 \%\right)$ or high-alkali tholeiite $\left(\mathrm{Al}_{2} \mathrm{O}_{3}<16.5 \%\right)$, and between high-alkali tholeiite and low-alkali tholeiite are shown (Kuno, 1966). Most of the samples plotted in the high-alumina basalt field, and the basaltic rocks should belong to either high-alkali tholeiite series or high-alumina 


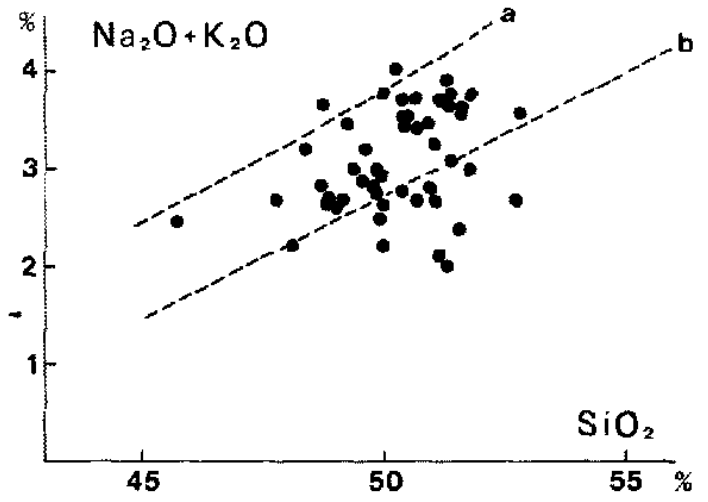

Fig. 2. Total alkalì-silica diagram. a, boundary between alkall and highalumina basalt series; $b$, boundary between high-alumina basalt and tholeiite series (Kuno, 1966).

basalt series.

A few of the samples contain normative olivine, however, normative quart $z$ (up to $10 \%$ ) was calculated in most of the samples. Recalculation on the assumption that $\mathrm{FeO} /(\mathrm{FeO}+$ $\mathrm{Fe}_{2} \mathrm{O}_{3}$ ) ranged from $0.10-0.15$ before alteration, demonstrates that most of these rocks are olivine normative. Although a few of them are still quartz normative, the calculated $Q$ no longer exceeds $5 \%$.

The $\mathrm{Mg}$-value is used as an index of the degree of differentiation since the $\mathrm{SiO}_{2}$ contents very little. The relations between the major oxides and the $\mathrm{Mg}$-value are shown in Fig. 3. Their $\mathrm{TiO}_{2}, \quad \mathrm{FeO} *\left(\mathrm{FeO}+0.9 \mathrm{Fe}_{2} \mathrm{O}_{3}\right)$, $\mathrm{Na}_{2} \mathrm{O}$, and $\mathrm{K}_{2} \mathrm{O}$ contents gradually increase with the decreasing $\mathrm{Mg}$-value while the $\mathrm{MgO}$ content decreases. The $\mathrm{CaO}$ content initially increases but starts decreasing after passing the $\mathrm{Mg}$-values of 50 . The $\mathrm{SiO}_{2}$ and $\mathrm{Al}_{2} \mathrm{O}_{3}$ values are rather constant through the entire range of $\mathrm{Mg}$-values.

Trace elements: The trace element abundances are plotted against the Mg-value in Fig. 4. The compatible elements ( $\mathrm{Cr}$ and $\mathrm{Ni}$ ) decrease rapidly while $\mathrm{Mg}$-value is between 70 and 50 and parallel to the trend of gradually as another compatible element, $\mathrm{Co}$ after 50. Gradual and systematic increases are characteristic of such incompatible elements as $\mathrm{Ce}, \mathrm{F}$, $\mathrm{Sc}, \mathrm{Sr}, \mathrm{V}, \mathrm{X}$, and $\mathrm{Zr}$. Although $\mathrm{Ba}$ and $\mathrm{Rb}$ increase, they show much scatter at high $\mathrm{Mg}$ values.

Most of the major and trace element data seem indicative of either a simple fractional crystallization from a primary magma or a different degree of partial meiting of mantle material under common conditions as the cause of the diversity of the samples. However, mantle heterogeneity and/or crustal contamination might have been responsible for the scattered abundances of $\mathrm{K}, \mathrm{Rb}$, and $\mathrm{Ba}$ in the picritic to basaltic rocks and the $\mathrm{Sr}$ isotopic data may also require either or both of the processes.

\section{Mineralogy}

Eight representative rocks, which are medium- to coarse-grained and holocrystalline with trace to negligible amounts of pale brown glass in groundmass, were selected for minera] analysis : one picritic dolerite, one basalt, one dolerite, and five ferrodolerites. Mineral compositions were determined with an electron microanalyzer according to our routine procedure (Fujimaki and Aoki, 1980). The selected analytical results are given in Tables 2 to 5 ,

Plagioclase: Plagioclases are zoned normally and their composition ranges form $\mathrm{An}_{79^{-}}$ $A n_{52}$. The Or contents are $0.5-1 \%$ for $\mathrm{An}_{79}$ $\mathrm{An}_{70}$ and they slowly increase with a decrease in An component; plagioclase of $\mathrm{An}_{50}$ has $2 \%$ Or content and plagioclase of $\mathrm{An}_{35}$ has $6 \%$. The compositional range of the plagioclase as well as its or component are comparable to those of basalts and ferrobasalts of the other tholeiitic suites elsewhere. Note an increase in $\mathrm{Ab}$ content (Fig. 5) with differentiation from picritic dolerite to ferrodolerite. The most sodic compositions and the narrowest ranges in 

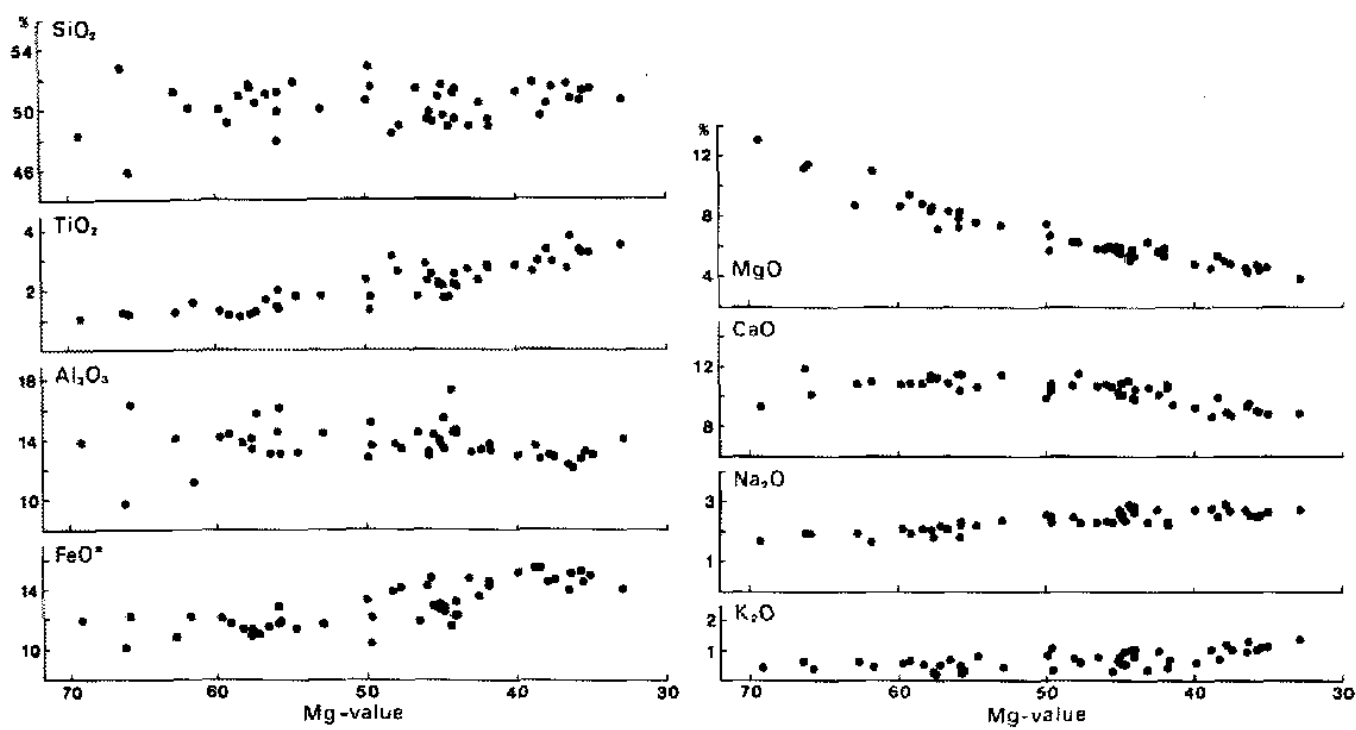

Fig. 3. Major oxides-Mg-value variation diagram.

composition are characteristic of the plagioclases occur in the mesostasis in the ferrodolerites; such compositions are comparable to those of the outermost margins of the ground mass plagioclases. Alkali feldspar can be identified but it is too small to be analyzed.

Olivine: Individual analyses of olivine in the samples are plotted in Fig. 6 in terms of atomic percent $\mathrm{Ca}, \mathrm{Mg}$, and $\mathrm{Fe}$ together with coexisting clinopyroxene. The range of olivine composition is much broader $\left(\mathrm{Fa}_{14}-\mathrm{Fa}_{95}\right)$ that for the other minerals. Although $\mathrm{CaO}$ wt\% is within $0.2-0.5$ for the phenocryst olivines as well as groundmass ones regardless of $\mathrm{Fa}$ content, the fayalitic olivines in the mesostasis are rather enriched in $\mathrm{CaO}(0.5-0.6$ wt\%). The $\mathrm{MnO}$ contents range for $0.25-1.5$ wt\% ; they positively correlate with Fa compo. nent. The most magnesian olivine was found in a picritic dolerite sample (GI-67). Its phenocryst olivines have a range of $\mathrm{Fa}_{14-21}$ and the groundmass ones $\mathrm{Fa}_{21-48}$. The $\mathrm{NiO}$ content in the olivine of $\mathrm{Fa}_{14}$ is $0.37 \mathrm{wt} \%$ but since it rapidly decreases with an increase in Fa component, the $\mathrm{NiO}$ content is $0.1 \mathrm{wt} \%$ or less in the olivines of $\mathrm{Fa}_{30}$. The chemical composition of the phenocryst and groundmass olivines varies gradually from $\mathrm{Fa}_{14}$ in the picritic basalt to $\mathrm{Fa}_{88}$ in the ferrobasalt. The most fayalitic olivines were observed in the mesostasis of some ferrodolerites; they appear as microlites whose composition ranges from $\mathrm{Fa}_{77}$, which is equivalent to the outermost margins of the most fayalitic groundmass olivine, to $\mathrm{Fa}_{95}$ in a ferrodolerite ( $\mathrm{PN}-30)$.

Clinopyroxene: The $\mathrm{Mg}$-value of the most magnesian diopsidic augite $\left(\mathrm{Wo}_{42} \mathrm{En}_{46} \mathrm{FS}_{12}\right)$ is 80 that is rather smaller than the 86 of olivines. The diopsidic augites contain $0.4-1.1 \mathrm{wt} \% \mathrm{Cr}_{2} \mathrm{O}_{3}$ but the chromium content decreases rapidly with an increase in $\mathrm{FeO}$. The $\mathrm{Mg}-\mathrm{Fe}$ substitution changes clinopyroxene compositions in the picritic basalt and dolerite along the $\mathrm{CaMg}$ $\mathrm{CaFe}$ line. The $\mathrm{Ca}-\mathrm{Fe}$ substitution takes over the $\mathrm{Mg}-\mathrm{Fe}$ substitution in a basaltic composition : the crystallization trend of clinopyroxene seems subparallel to the $\mathrm{CaFe}-\mathrm{Fe}$ join. The ferrobasalts and ferrodolerites include Fe-rich augite as well as pigeonite. The modal abun. dance in the groundmass of the latter is as 

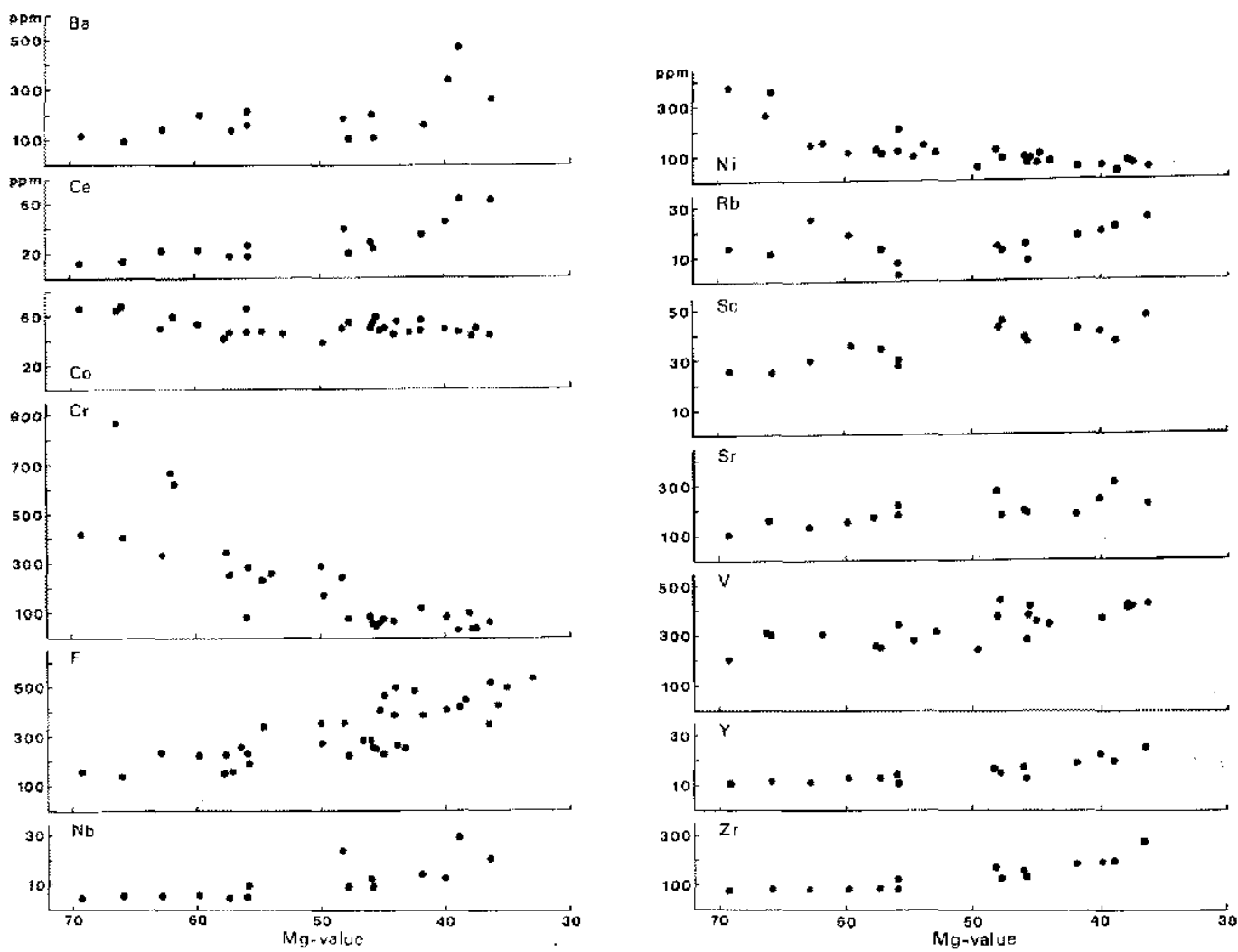

Fig. 4. Trace elements-Mg-value variation diagram.

small as $1 / 10$ of the former. The most Fe-rich clinopyroxene appears in the mesostasis with fayalitic olivine. Abundant ferroaugite $(\mathrm{Mg}$ value $=28-39$ ) coexists with less abundant pigeonite $(\mathrm{Mg}$-value $=50-55)$ in the mesostasis of a ferrodolerite $\mathrm{PN}-30$, while no ferroaugite was recognized in a ferrodolerite $\mathrm{PN}-22$. Instead, PN-22 contains the most Fe-rich clinopyroxene which is ferropigeonite (Mg-value $=62-65$ ). No orthopyroxene was found in the samples from the Deccan tholeiitic suite.

In Fig. 7, the averaged compositions of clinopyroxenes in the samples, including those in the mesostasis of a ferrodolerite $\mathrm{PN}-22$, were shown with the averaged composition of groundmass clinopyroxenes of tholeiitic suites from $\mathrm{l} z \mathrm{u}-\mathrm{Hak}$ ne region and Nasu volcanic zone, Japan for comparison. It is well recog- nized that clinopyroxene crystallization trends in alkalic suites are parallel or subparallel to the $\mathrm{CaMg}-\mathrm{CaFe}$ join. By contrast, Kuno (1955) emphasized that the $\mathrm{Ca}-\mathrm{Fe}$ substitution turned toward ferrosilite in tholeiitic suites. Note a more clearly defined crystallization trend from diopside toward ferrosilite has been determined for the Deccan tholeiitic suite than that of IzuHakone tholeiitic suite in Fig. 7. Although Aoki (1967) discovered that augite was the first pyroxene phase in the groundmass of the olivine tholeitic suite and pigeonite started crystallizing side by side with augite with further crystallization, the nature of the relationship between the pyroxenes has long been in doubt: as no one knew the composition of the clinopyroxene when pigeonite starts crystallizing. The present study has established that as 
Table 2. EPMA analyses of representative plagioclases

\begin{tabular}{|c|c|c|c|c|c|c|c|c|c|c|}
\hline \multirow{3}{*}{ Sp. No. } & 1 & 2 & 3 & 4 & 5 & 6 & 7 & 8 & 9 & 10 \\
\hline & \multicolumn{2}{|c|}{$61-67$} & \multicolumn{2}{|c|}{$P H-21$} & \multicolumn{3}{|c|}{$P N-30$} & \multicolumn{3}{|c|}{$\beta N-22$} \\
\hline & $G r-C$ & $G r-R$ & 6 & $\mathrm{R}$ & $c$ & $R$ & $M$ & $c$ & $\mathrm{R}$ & $M$ \\
\hline $\mathrm{SiO}_{2}$ & 47.98 & 55.52 & 49.98 & 60.16 & 51.25 & 59.50 & 60.19 & 53.54 & 57.72 & 59.66 \\
\hline $\mathrm{A}_{2} \mathrm{O}_{3}$ & 32.42 & 27.53 & 31.33 & 24.78 & 30.30 & 25.12 & 29.88 & 28.88 & 25.81 & 24.78 \\
\hline $\mathrm{Fe}_{2} \mathrm{O}_{3}$ & & 1.05 & 0.70 & 0.48 & 0.57 & 0.70 & 0.76 & & & $0.7 t$ \\
\hline $\mathrm{CaO}$ & 16.32 & 10.31 & 14.78 & 6.56 & 13.63 & 7.37 & 7.04 & 11.82 & 7.97 & 6.56 \\
\hline $\mathrm{Na}_{2} \mathrm{O}$ & 2.35 & 4.99 & 81 & 7.42 & 3.70 & 6.54 & 6.85 & .53 & 6.28 & 6.84 \\
\hline $\mathrm{K}_{2} \mathrm{O}$ & 0.09 & 0.51 & 0.09 & 0.56 & 0.35 & 0.58 & 0.57 & 0.48 & 0.78 & 0.88 \\
\hline Total & 99.77 & 99.92 & 99.69 & 99.96 & 99.90 & 99.81 & 100.29 & 100.05 & 99.19 & 99.43 \\
\hline $\mathrm{mol}$ \% & 78.9 & 51.7 & 73.9 & 31.8 & 65.7 & 37.0 & 35.0 & 57.4 & 39.4 & 32.8 \\
\hline
\end{tabular}

$\mathrm{Ph}$, phenocryst; Gr, groundmass; $C$, core; $R$, rim; $M$, mesostasis.

long as the atomic $\mathrm{Ca}$ of clinopyroxene $[100$ $\mathrm{Ca} /(\mathrm{Ca}+\mathrm{Mg}+\mathrm{Fe})]$ is more than 35 , no pigeonite crystallizes. When the atomic $\mathrm{Ca}$ decreases less than that, pigeonite starts crystallizing. In the groundmass of the tholeiitic suite of $\mathrm{Izu}-\mathrm{Hakone}$ region, augite and pigeonite coexist ; both have the atomic $\mathrm{Ca}$ less than 35 . Pigeonite precedes augite crystallization in the groundmass of the tholeiitic suite of Nasu zone. The atomic $\mathrm{Ca}$ is less than 25 for both. The pyroxene compositional relation can be summarized as follows: Augite alone crystallizes when its atomic $\mathrm{Ca}$ is more than 35 and pigeonite should precede augite when the atomic $\mathrm{Ca}$ is less than 25. Either pigeonite or augite precedes the other when the $\mathrm{Ca}$ is between 35 and 25. This is consistent with the experimental phase relation between augite and pigeonite; Kushiro (1972) demonstrated the existence of the cotectic line in the center of the pyroxene quadrilateral at the magnesian side.

Iron oxides: The titanomagnetites included consist of a series of ulvospinel-magnetite solid solution (98-95\%) and the spinel-hercynite component ranges for $5-2 \%$. Their picrochromite-chromite component is hardly more than $0.4 \%$. Most of the titanomagnetites are enriched in $\mathrm{TiO}_{2}$ and their ulvospinel moles are for $76-60 \%$, while a few of them have $55-27 \%$. The maximum: amounts of $\mathrm{MgO}$ and $\mathrm{MnO}$ are 1.7 and $1.4 \mathrm{wt} \%$, respectively. Commonly they carry between $0.2-0.8 \mathrm{wt} \% \mathrm{MgO}$. The chemical compositions of the titanomagnetites seem independent of the coexisting mafic minerals. Ilmenites are rather depleted in hematite mole (8-3\%) and contain minor amounts of $\mathrm{MnO}$

Table 3. EPMA analyses of representative olivines

\begin{tabular}{|c|c|c|c|c|c|c|c|c|c|c|c|}
\hline \multirow{3}{*}{ 5p. №. } & 1 & 2 & 3 & 4 & 5 & 6 & 7 & 8 & 9 & 10 & 11 \\
\hline & \multicolumn{4}{|c|}{ GI $\div 67$} & \multicolumn{2}{|c|}{$P N-21$} & \multicolumn{4}{|c|}{$P K-30$} & $\mathrm{PN}-22$ \\
\hline & $\mathrm{Ph}-\mathrm{C}$ & $P h-R$ & $G r+C$ & $\mathrm{Gr}-\mathrm{R}$ & $c$ & $R$ & C & $R$ & $y$ & $M$ & $\bar{M}$ \\
\hline $\mathrm{SiO}_{2}$ & 39.96 & 38.32 & 36.74 & 34.97 & 37.78 & 33.27 & 36.30 & 31.62 & 31.70 & 29.92 & 30.64 \\
\hline Feo & 13.48 & 21.11 & 31.33 & 39.59 & 25.41 & 50.24 & 30.71 & 57.38 & 57.30 & 65.15 & 64.27 \\
\hline Mno & 0.26 & 0.37 & 0.60 & 0.80 & 0.39 & 0.87 & 0.47 & 1.11 & 1.08 & 1.49 & 1.26 \\
\hline $\mathrm{MgO}$ & 45.56 & 39.63 & 31.13 & 24.08 & 36.02 & 15.64 & 31.36 & 9.40 & 9.85 & 2.27 & 3.59 \\
\hline $\mathrm{NiO}$ & 0.37 & 0.14 & & & & & & & & & \\
\hline $\mathrm{CaO}$ & 0.28 & 0.30 & 0.41 & 0.40 & 0.29 & 0.28 & 0.33 & 0.38 & 0.40 & 0.54 & 0.59 \\
\hline Totai & 99.91 & 99.87 & 100.21 & 99.84 & 99.89 & 100.30 & 99.17 & 99.89 & 100.33 & 99.37 & 100.35 \\
\hline Fo mol $\%$ & 85.8 & 77.0 & 63.9 & 52.0 & 71.7 & 35.7 & 64.5 & 22.6 & 23.4 & 5.8 & 9.0 \\
\hline
\end{tabular}


Table 4. EPMA analyses of representative clinopyroxenes

\begin{tabular}{|c|c|c|c|c|c|c|c|c|c|c|c|c|c|c|}
\hline \multirow{3}{*}{ Sp. No. } & 1 & 2 & 3 & 4 & 5 & 6 & 7 & 8 & 9 & 10 & 11 & 12 & 13 & 14 \\
\hline & \multicolumn{2}{|c|}{ GI-6] } & \multicolumn{4}{|c|}{$P K-21$} & \multicolumn{4}{|c|}{$P N-30$} & \multicolumn{4}{|c|}{$\because \mathrm{PN}-22$} \\
\hline & $\mathrm{Gr}-\mathrm{C}$ & $G r-R$ & $c$ & $R$ & $c$ & $\mathrm{R}$ & C. & $\mathrm{R}$ & $M$ & $M$ & C & $\mathrm{R}$ & C & M \\
\hline $\mathrm{SiO}_{2}$ & 49.64 & 48.62 & 50.77 & 49.74 & 51.90 & 51.04 & 52.07 & 49.97 & 48.09 & 50.97 & 49.69 & 49.66 & 52.50 & 48.46 \\
\hline $\mathrm{TiO}_{2}$ & 0.90 & 2.30 & 0.80 & 0.57 & 0.56 & 0.49 & 0.58 & 0.77 & 0.90 & 0.37 & 1.34 & 0.71 & 0,41 & 0.51 \\
\hline $\mathrm{A}_{2} \mathrm{O}_{3}$ & 4.89 & 3.41 & 3.07 & 1.15 & 1.36 & 1.03 & 2.12 & 1.36 & $: .46$ & 0.79 & 3.27 & 1.54 & 0.97 & 1.00 \\
\hline $\mathrm{Cr}_{2} \mathrm{O}_{3}$ & 0.89 & & & & & & & & & & & & & \\
\hline $\mathrm{FeO}$ & 7.51 & 14.79 & 9.21 & 26.24 & 21.25 & 27.70 & 9.80 & 21.60 & 28.79 & 26.77 & 12.01 & 23.58 & 21.82 & 36.82 \\
\hline Mno & 0.14 & 0.45 & 0.18 & 0.73 & 0.54 & 0.70 & 0.21 & 0.57 & 0.79 & 0.61 & 0.24 & 0.55 & 0.48 & 0.85 \\
\hline $\mathrm{MgO}$ & 14.47 & 10.87 & 15.01 & 10.22 & 18.70 & 14.27 & 15.60 & 9.63 & 5.27 & 15.62 & 14.11 & 10.25 & 19.26 & 8.60 \\
\hline $\mathrm{CaO}$ & 21.09 & 19.91 & 19.59 & 11.29 & 5.66 & 5.17 & 19.24 & 16.16 & 14.67 & 4.34 & 18.43 & 13.27 & 4.71 & 4.07 \\
\hline $\mathrm{Na}_{2} \mathrm{O}$ & 0.47 & 0.35 & 0.44 & 0.12 & 0.36 & 0.41 & 0.21 & 0.12 & 0.16 & 0.19 & 0.40 & 0.44 & 0.12 & 0.10 \\
\hline Total & 100.00 & 100.70 & 99.07 & 100.07 & 100.33 & 100.81 & 99.83 & 100.18 & 100.13 & 99.66 & 99.40 & 100.00 & 100.27 & 100.41 \\
\hline Ca atom \% & $\% 44.7$ & 42.4 & 41.0 & 24.3 & 11.7 & 11.0 & 39.5 & 34.5 & 32.5 & 9.1 & 38.7 & 28.6 & 9.6 & 9.0 \\
\hline $\mathrm{Mg}$ & 42.7 & 32.2 & 43.7 & 30.5 & 53.4 & 42.0 & 44.5 & 28.6 & 16.3 & 45.8 & 41.2 & 30.8 & 54.8 & 26,3 \\
\hline $\mathrm{Fe}$ & 12.7 & 25.4 & 15.3 & 45.2 & 34.9 & 47.0 & 16.0 & 36.9 & 51.2 & 45.1 & 20.1 & 40.6 & 35.6 & 64.7 \\
\hline
\end{tabular}

(0.5-0.9 wt\%) and $\mathrm{MgO}(0.2-1.7 \mathrm{wt} \%)$.

Glass in mesostasis: Pale brown glasses, filling the mesostasis in the samples include Ferich mafic minerals and sodic plagioclase. Although the glasses are rather heterogeneous, they are rhyolitic; the average composition of the glass in $\mathrm{PN}-22$ ferrodolerite is as follows: $\mathrm{SiO}_{2}, 72.42 ; \mathrm{TiO}_{2}, 0.58 ; \mathrm{Al}_{2} \mathrm{O}_{3}, 14.69 ; \mathrm{FeO}^{*}$, $2.04 ; \mathrm{MgO}, 0.27 ; \mathrm{CaO}, 1.11 ; \mathrm{Na}_{2} \mathrm{O}, 4.90 ; \mathrm{K}_{2} \mathrm{O}$, 3.99. Rhyolitic lavas are very rare in the Deccan plateau but their compositions are quite similar to this. The similarity is indicative of

Table 5. EPMA analyses of representative iron oxides

\begin{tabular}{|c|c|c|c|c|c|c|c|}
\hline \multirow{3}{*}{ Sp. No. } & 1 & 2 & 3 & 4 & 5 & 6 & 7 \\
\hline & $67-67$ & \multicolumn{2}{|c|}{$\mathrm{PN}-21$} & \multicolumn{4}{|c|}{$\mathrm{PNS}_{-22}$} \\
\hline & $M t$ & At & [1] & $\mathrm{Mt}$ & 11 & $M t-M$ & $11-M$ \\
\hline $\mathrm{TiO}_{2}$ & 25.80 & 23.94 & 50.28 & 24.00 & 49.99 & 25.37 & 50.68 \\
\hline $\mathrm{A}_{2} \mathrm{O}_{3}$ & 2.01 & 1.13 & & 1.79 & 0.12 & 1.71 & 0.15 \\
\hline $\mathrm{Cr}_{2} \mathrm{O}_{3}$ & 0.25 & & & 0.24 & & 0.23 & \\
\hline $\mathrm{V}_{2} \mathrm{O}_{3}$ & 1.10 & 0.81 & & 0.85 & 0.36 & 0.70 & 0.14 \\
\hline $\mathrm{Fe}_{2} \mathrm{O}_{3} *$ & 15.80 & 20.32 & 5.16 & 19.57 & 4.40 & 17.23 & 3.48 \\
\hline $\mathrm{FeO}$ & 51.88 & 51.85 & 41.26 & 52.65 & 42.95 & 53.72 & 43.77 \\
\hline Mno & 0.59 & 0.76 & 0.53 & 0.33 & 0.60 & 0.31 & 0.63 \\
\hline MgO & 1.73 & 0.42 & 1.86 & 0.43 & 0.78 & 0.55 & 0.65 \\
\hline Total & 99.16 & 99.23 & 99.19 & 99.86 & 99.20 & 99.82 & 99.50 \\
\hline
\end{tabular}

* Calculated as $\mathrm{FeO}$ and $\mathrm{Fe}_{2} \mathrm{O}_{3}$ assuming stoichiometry. Mt, titanomagnetite; $I 1$, iTmenite; $M$, in mesostasis. a crystallization differentiation from the as. sociated olivine tholeitic magma as a plausible mechanism for the origin of the rhyolitic liquid.

\section{Discussion}

We summarized the petrographical, mineralogical, and geochemical features of the samples which represent the most abundant olivine tholeiite suites in the Deccan plateau basalt group as follows:

(1) Olivine is the commonest phenocryst and plagioclase is subordinate. Augite phenocrysts are rare. The major groundmass mineral assemblage is common for all the rock suite. Olivine coexists with augite in the groundmasses of all the samples and continuously changes in composition towards the $\mathrm{Fe}$ rich end. Pigeonite crystallization is delayed and starts in an olivine basaltic composition. In the latest stage ferropigeonite cocrystallizes with fayalite but no ferroaugite appears. Plagioclase ranges in composition from calcic to sodic.

(2) Pigeonite geothermometry (Ishii, 1975) provides the pigeonite liquidus temperatures for the ferrobasalts and the rhyolitic mesos- 


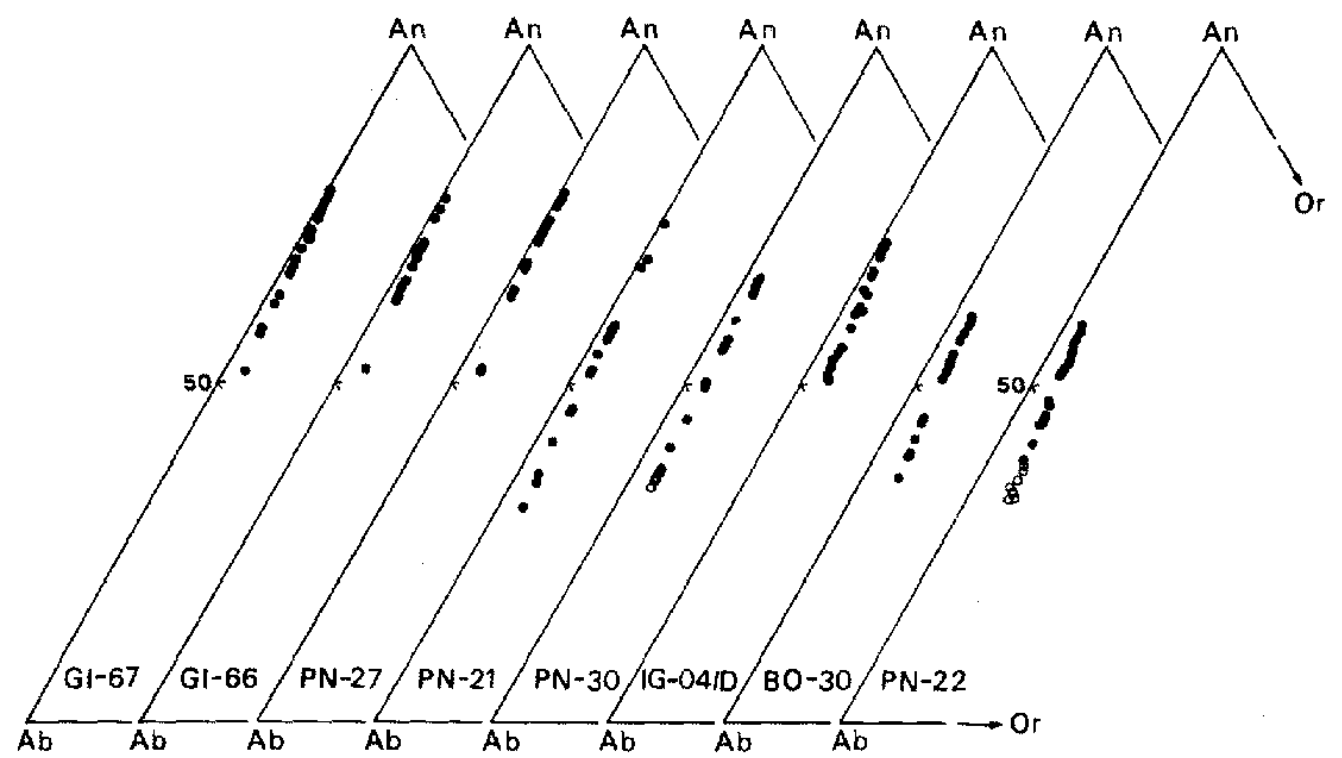

Fig. 5. EPMA analyses of plagioclases in mole percent anorthite (An), albite (AB) and orthoclase (Or).

Solid circle, phenocrystic and groundmass plagioclase; open circle, mesostasis plagioclase.

tasis; they are $1100^{\circ} \mathrm{C}$ and $930^{\circ} \mathrm{C}$, respectively. Each of them is within an acceptable range. The temperature of the least differentiated picritic basalt magma must have been higher than $1100^{\circ} \mathrm{C}$ when it erupted.

(3) All the major elements vary gradually without any abrupt change.

(4) Most of the trace elements vary systematically and no sudden shift is recognized in their variation diagrams as well.

Previous geochemical investigations (Aramaki and Kohno, 1975; Alexander and Gibson, 1977 ; Alexander and Paul, 1977 ; Kurasawa et al., 1982 ; Mahoney et al., 1982 ; Paul et al., 1984) revealed that the Deccan tholeitic suites were highly enriched in LREE with $\mathrm{La} / \mathrm{Yb}$ ratios of $3.86-6.33$. Some of the basaltic rocks have either negative or positive Eu anamalies. Their Sr isotopic ratios vary between $0.70393-0.71972$.

Recently, Norry and Fitton (1983), Cox (1983), and Thompson et al. (1983) proposed a new model to account for the diversity of conti- nental flood basalts. According to them, the following four explanations are appropriate: 1) different degree of partial melting, 2) heterogeneity of upper mantle materials, 3) crystallization differentiation, and 4) crustal contamination.

Alexander and Paul (1977) and Kurasawa et al. (1982) noticed no positive correlation between $\mathrm{Sr}$ isotopic ratios and major element variations; accordingly, they rejected the idea of crustal contamination. Our data confirm the improbability of contamination as well (see Table 1). Some picritic basalts have very high $\mathrm{Sr}$ isotopic ratios and some differentiated ones have low ratios. If crustal contamination plays a significant role in generating diversity, a correlation between $\mathrm{Sr}$ isotopes and major ele. ments should exist to some extent. Some one may propose selective transportation of $\mathrm{Sr}$ from basement granitic rocks but it is difficult to envisage a practical mechanism for doing this. Therefore, crustal contamination is not acceptable. 

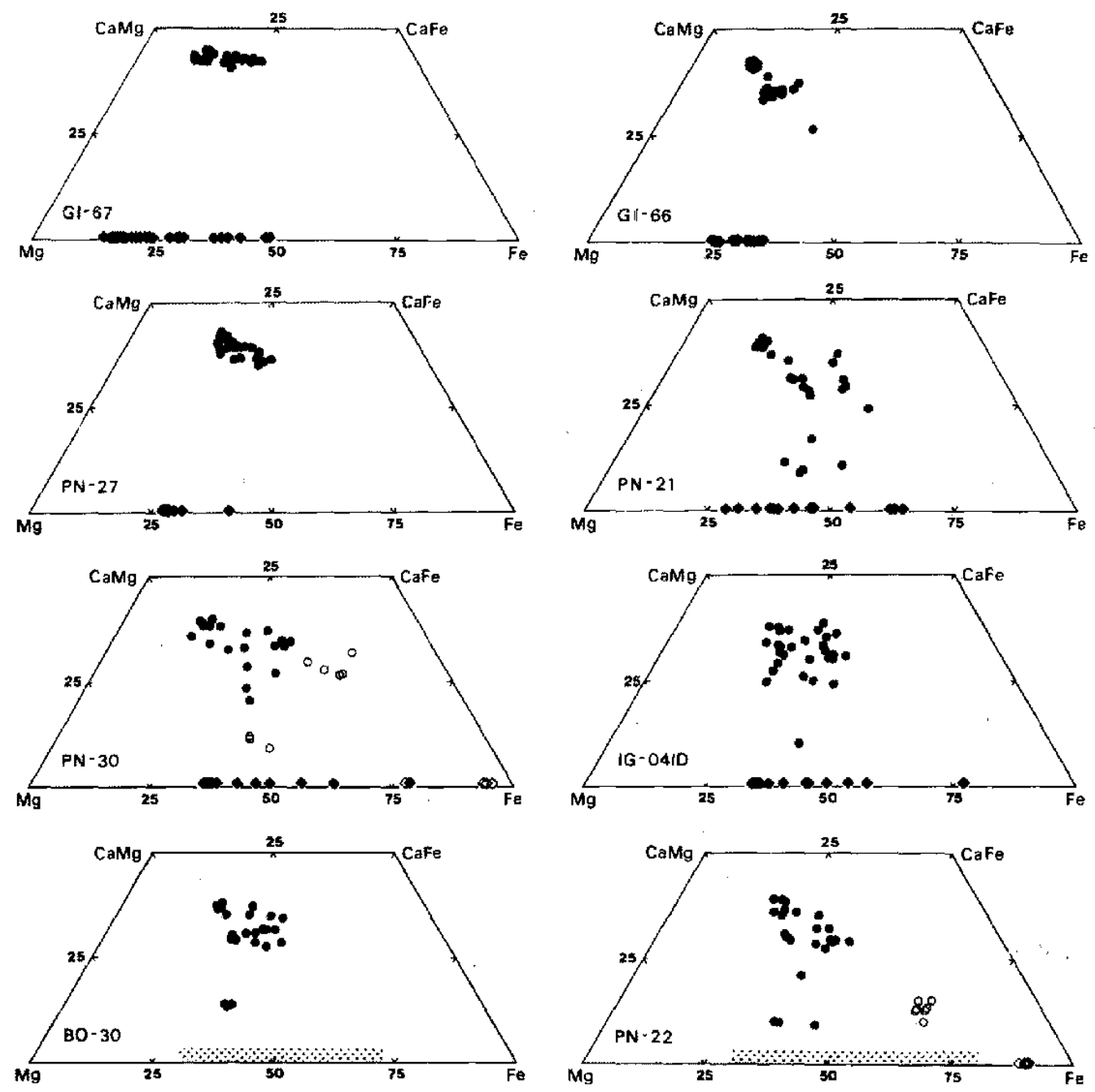

Fig. 6. EPMA analyses of olivine and clinopyroxene in atomic percent $\mathrm{Ca}, \mathrm{Mg}$ and $\mathrm{Fe}+\mathrm{Mn}$.

Solid square, phenocrystic and groundmass olivine; open square, mesostasis olivine; dotted area, estimated composition of altered groundmass olivine; solid circle, phenocrystic and groundmass clinopyroxene; open circle, mesastasis clinopyroxene.

Fractional crystallization is one of the best candidates for the cause of the diversity of flood basalts. We examine the possibility in a $\mathrm{MgO}$ $\mathrm{FeO}^{*}-\mathrm{Na}_{2} \mathrm{O}+\mathrm{K}_{2} \mathrm{O}$ diagram (Fig. 8). The differentiation trend is nearly parallel to the $\mathrm{MgO}-\mathrm{FeO}^{*}$ line and demonstrates a progressive iron enrichment. The variation corresponds to the beginning half of the Skaergaard trend, which is regarded as a result of crystallization differentiation under high temperature and low oxygen partial pressure. We marked three points on the $\mathrm{MgO}-\mathrm{FeO}^{*}$ line in Fig. 8 , that indicate the $\mathrm{Mg} / \mathrm{Fe}$ ratios of $\mathrm{Fo}_{85}, \quad \mathrm{FO}_{80}$ and $\mathrm{Fo}_{75}$. An extrapolation of the variation trend crosses the line between $F_{O_{85}}$ and $F_{O_{80}}$; this is suggestive of an effective fractionation of olivine $\left(\mathrm{FO}_{85}-\mathrm{Fo}_{80}\right)$ in the differentiation. The petrographic and geochemical natures of the basaltic suite are well consistent with this estimation. The rapid decreases in $\mathrm{Ni}$ and $\mathrm{Cr}$ 


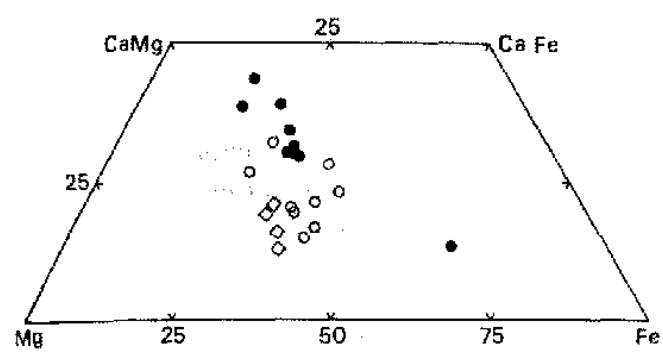

Fig. 7. Average composition of groundmass and mesostasis clinopyroxenes.

Solid circle, Deccan basalts; open circle. Izu-Hakone tholeiite (Kuno, 1955); open square, Nasu zone tholeite (Aoki, unpubl.).

(contained in spinel inclusion in olivine) abundances should be a proof of the significant olivine fractionation in forming the fer. robasalts from the picritic basalts as well.

The major constituents of the mantle peridotite may not contain significant amounts of such highly incompatible elements as $\mathrm{K}, \mathrm{Ba}, \mathrm{Ce}$, $\mathrm{F}, \mathrm{Rb}, \mathrm{Sr}$, and $\mathrm{Zr}$. They may rather be includ. ed in some minor constituents like pargasite, phlogopite, and apatite. These elements should be selectively concentrated in a mamga with melting and exclusively enriched in the residual liquid with fractional crystallization until some rare minerals, with which these elements are compatible, start crystallizing. Among them $\mathrm{Sr}$ also follows the scheme before sodic plagioclase crystallizes. Therefore, the enrichments in these elements should be parallel to the initial abundances in a parental magma during early to middle stage of fractional crystallization. The parallel increases in the incompatible elements in the samples are suggestive of homogeneous mantle sources of the parental magmas.

The abundance ratios (incompatible element $/ \mathrm{K}$ ) of the samples are restricted in narrow ranges with a few exceptional elements and so are those of the other Deccan basaltic rocks. The trace element abundance patterns of the samples normalized by an assumed

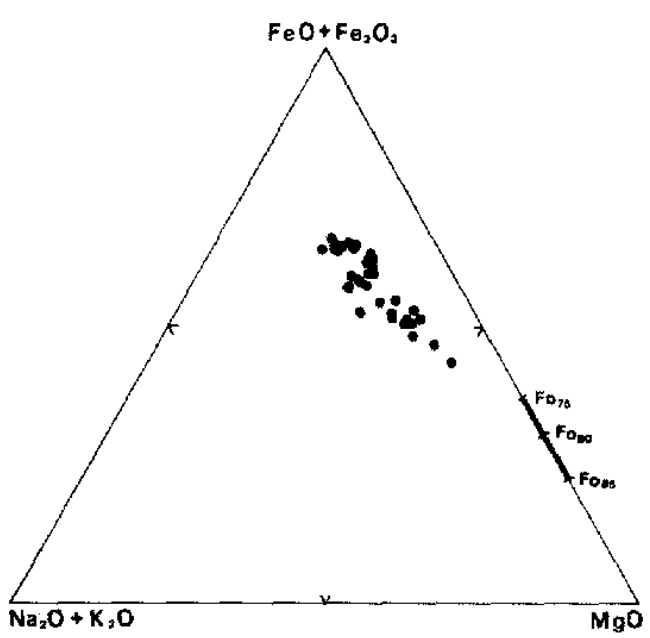

Fig. 8. $\mathrm{MgO}-\left(\mathrm{FeO}+\mathrm{Fe}_{2} \mathrm{O}_{3}\right)-\left(\mathrm{Na}_{2} \mathrm{O}+\mathrm{K}_{2} \mathrm{O}\right)$ dia gram.

primodial upper mantle are equivalent to those of the continental flood basalts (cf. Norry and Fitton, 1983; Cox, 1983; Thompson et al., 1983; Yoshida and Aoki, 1986). They have neither strong positive $\mathrm{Ba}$ nor negative $\mathrm{Nb}$ anomaly common to the island arc tholeite (Yoshida and Aoki, 1984). They show no such abrupt depletions in $\mathrm{K}, \mathrm{Nb}, \mathrm{Ba}$, and $\mathrm{Rb}$ as MORB does. Accordingly, a particular heterogeneity is highly unlikely in the mantle source region of the basaltic rocks. However, no correlation between $\mathrm{Sr}$ isotopes and $\mathrm{Rb} / \mathrm{Sr}$ ratios of the samples does require an extreme heterogeneity of $\mathrm{Sr}$ isotopic abundances in the source. In combination with the results of high-temperature and high-pressure experiments, we interpret the petrological and geochemical features of the picritic basalt and ferrobasalt suite as follows:

1) Picritic olivine tholeiite magma was produced by a partial melting of the upper mantle peridotite (possibly $50 \mathrm{~km}$ deep) which presumably had the trace element abundances rather close to the assumed primodial mantle. The mantle material might have been rather depleted in $\mathrm{Sr}$ and highly heterogeneous in 
isotopic abundances.

2) The low-pressure fractional crystallization dominated by olivine, accompanied by augite and plagioclase to a lesser extent, produced the sequence of the picritic basaltbasalt-ferrobasalt from a parental olivine tholeiite magma.

Acknowledgements: The authors are indebted to Dr. S.S. Deshmuk, Geological Survey of India, Nagpur, India for his kind assistance with the field work. A part of expenses of this study was defrayed by a Grant-in-Aid for Overseas Scientific Survey (1973) and Scientific Research (No.02453045) from the Ministry of Education, Science, and Culture of Japan.

\section{References}

Alexander, P.O. and Gibson, I.L. (1977), Rare earth abundances in Deccan Trap basalts. Lithos, 10, 143-147.

Alexander, P.O. and Paul, D.K. (1977), Geochemistry and strontium isotopic composition of basalts from the eastern Deccan volcanic prov. ince, India. Mineral. Mag., 41, 165-172.

Aoki, K. (1967), Petrography and petrochemistry of latest Pliocene olivine-tholejites of Taos area, northern New Mexico, U.S.A. Contrib. Mineral. Petrol., 14, 190-203.

Aramaki, S. and Kohno, M. (1975), Deccan Trap basalts. Kagaku, 45, 286-295 (in Japanese).

Boss, M.K. (1972), Deccan basalts. Lithos, 5, 131145 ,

Cox, K.G. (1983), The Karoo province of southern Africa: origin of trace element enrichment patterns. In: C.J. Hawkesworth and M.J. Norry eds., Continental basalts and mantle xenoliths. Shiva Publ, Cheshire, pp. 139-157.

Fujimaki, H. and Aoki, K. (1980), Quantitative microanalyses of silicates, oxides and sulfides using an energy-dispersive type electron probe. Sci. Rep. Tohoku Univ., Ser. III, 14, 241-268.

Ingram, B.L. (1970), Determination of futoride in silicate rocks without separation of aluminium using a specific ion electrode. Anal. Chem., 42, 1825-1827.

Ishii, T. (1975), The relations between tempera. ture and composition of pigeonite in some lavas and their application to geothermometry. Mineval. $J$., 8, 45-57.

Kaneoka, I. $(1980),{ }^{40} \mathrm{Ar} /{ }^{39} \mathrm{Ar}$ dating on volcanic rocks of the Deccan Traps, India. Earth Planet. Sci. Lett., 46, 233-243.

Kanisawa, S. (1979), Content and behaviour of fluorine in granitic rocks, Kitakami moun. tains, Northeast Japan. Chem. Geol., 24, 5767.

Kesler, S.E., Van Loon, J.C. and Bateson, J.H. (1973), Analysis of fluorine in rocks and an application to exploration. J. Geochem. Ex. plor., 2, 11-17.

Kuno, H. (1955), Ion substitution in the diopsideferropigeonite series of clinopyroxenes. Amer. Mineral., 40, 70 93.

Kuno, H. (1966), Lateral variation of basalt magma type across continental margins and island arcs. Bull. Volcanol., 29, 195-222.

Kurasawa, H., Aramaki, S. and Deshmuk, S.S. (1982), Strontium isotopic geochemistry of volcanic suite from Deccan Traps and wester Japan arcs: implications for the origin of continental and arc volcanics. 5 th intern. Conf. Geochr. Cosmochr. Isotope Geol., Nikko, Japan (abstract).

Kushiro, 1. (1972), New method of determining liquidus boundaries with confirmation of incongruent melting of diopside and existence of iron-free pigeonite at $1 \mathrm{~atm}$. Carnegie Inst. Washing. Ann. Rep. Dir. Geophys. Lab., 1971$1972,603-607$.

Mahoney, J., Macdougall, I.D., Lugmair, G.W., Murali, A.V., Das Snaker, M. and Gopalan, K. (1982), Origin of the Deccan Trap flows at Mahabalshwar inferred from $\mathrm{Nd}$ and $\mathrm{Sr}$ isotopic and chemical evidence. Earth Planet. Sci. Lett., 60, 47-60.

Norry, M.J. and Fitton, J.G. (1983), Compositional differences between oceanic and continental basic lavas and their significance. In : C.J. Hawkesworth and M.J. Norry Eds. Continental basalts and mantle xenoliths. Shiva Publ., Cheshire, pp. 5 -19.

Paul, D.K., Kresten, P., Ray Barman, T, McNutt, R.H. and Brunfelt, A.O. (1984), Geochemical and petrological relations in some Deccan basalts, western Maharashtra, India. J. Volcanol. Geotherm. Res., 21, 165-175.

Thompson, R.N., Morrison, M.A., Dickin, A.P. and Hendry, G.L. (1983), Continenta] flood basalts...arachinds rule $\mathrm{OK}$ ? In : C.J. Haw. kesworth and M.J. Norry Eds. Continental 
basaits and mantle xenoliths: Shiva Publ., Cheshire, pp. 158-185.

Yoshida, T. and Aoki, K. (1984), Geochemistry of major and trace elements in the Quaternary volcanic rocks from Northeast Honshu, Japan. Sci. Rep. Tohoku Univ., Ser. III, 16, 1-34.

Yoshida, T. and Aoki, K. (1986), Geochemistry of some continental basalts. Sci. Rep. Tohokzt Univ., Ser, III, 16, 367-394.

Yoshida, T., Fujimaki, H. and Aoki, K. (1981),
Analysis of igneous rocks by instrumental photon-activation. Sci. Rep. Tohoku Univ., Ser. $I I, 15,101-119$.

Yoshida, T., Masumoto, K. and Aoki, K. (1986), Photon-activation analysis of standard rocks using an automatic $\gamma$-ray counting system with a micro-robot. J. Min. Petr. Econ. Geol., 81, 406-422.

\title{
デカン高原、ソレアイト質玄武岩の分別結晶作用について
}

\author{
青木謙一郎・吉田 武義・荒软 重雄・倉沢一
}

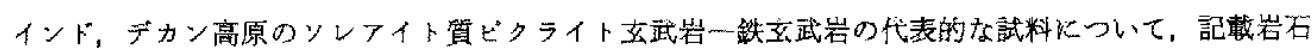

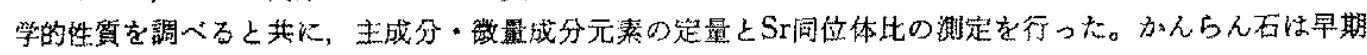

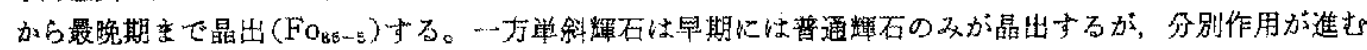

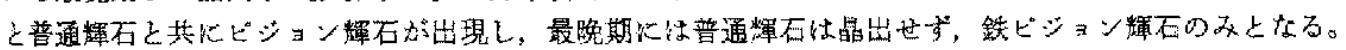

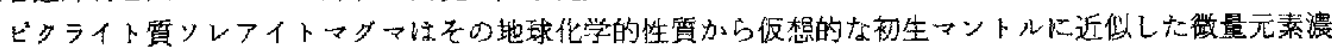
度党すったかんらん岩の部分融解によって生成したと推定される。ピクライト質玄武岩一玄武岩一鉄立武 岩の分化は低王下に打叮る普通輝石々斜長石を伴ら，主としてかんらん石の分別秸晶作用によって生じた。 